DOI: https://doi.org/10.24127/ajpm.v8i1.1711

\title{
PENGEMBANGAN MULTIMEDIA PEMBELAJARAN MATEMATIKA DENGAN PENDEKATAN MATEMATIKA REALISTIK
}

\author{
Dewi Wahyuni ${ }^{1}$, Rubhan Masykur ${ }^{2}$, Dona Dinda Pratiwi ${ }^{3}$ \\ ${ }^{\mathbf{1 , 2 , 3}}$ Pendidikan Matematika, UIN Raden Intan Lampung \\ E-mail: dwahyuni989@gmail.com ${ }^{l}$ \\ rmasykur@yahoo.co.id ${ }^{2)}$ \\ donadinda@radenintan.ac.id ${ }^{3)}$
}

Received 8 December 2018; Received in revised form 1 April 2019; Accepted 3 May 2019

\begin{abstract}
Multimedia is a combination of several media. The media used is Macromedia Flash and Sparkol Videoscribe. The purpose of this study was to determine the feasibility, attractiveness and effectiveness of the use of multimedia learning with the realistic mathematical approach of class VIII MTsN 2 Bandar Lampung. The development procedure used is the Borg and Gall design development model that has been cited by Sutopo into 7 stages, namely Potential and problems, Data collection, Product Design, Design Validation, Design Revision, Product Trial, and Product Revision. The results of the material expert research and media experts obtained a "Valid" criterion with an average value of 3.4 experts and a media expert of 3.3. Then the responses of students get the criteria of "Very Interesting" with an average score of 3.33, while effectiveness gets an average of 0.71 and is included in the high category.
\end{abstract}

Keywords: Multimedia; realistic mathematical

\section{PENDAHULUAN}

Pendidikan merupakan salah satu bagian penting dalam kehidupan manusia yang akan dibutuhkan sampai akhir hayat, karena pendidikan membuat manusia berusaha mengembangkan dirinya sehingga mampu menghadapi setiap perubahan yang terjadi dikehidupannya (Putra \& Anggraini, 2016). Salah satu bidang studi yang menduduki peranan penting dalam pendidikan yaitu matematika. Setidaknya hal itu bisa terlihat dari jam mata pelajaran matematika yang mendapat porsi lebih banyak disekolah dibanding pelajaran lainnya. Matematika juga termasuk mata pelajaran yang menjadi standar untuk diujikan ketika akan melanjutkan kejenjang yang lebih tinggi, sehingga matematika dapat dikatakan ilmu yang sangat berperan penting dalam kehidupan (Purwanti, Pratiwi, \&
Rinaldi, 2016). Matematika dapat diartikan adalah ilmu tentang logika mengenai bentuk, susunan, besaran dan konsep-konsep hubungan yang terbagi ke beberapa bidang (Mudlofir \& Rusydiyah, 2016). Dalam hal ini untuk mendukung proses pembelajaran dalam matematika dibutuhkan nya adanya media pembelajaran. Sadiman menyatakan bahwa media pembelajaran adalah bahan, alat, atau teknik yang digunakan dalam kegiatan belajar, mengajar dengan maksud agar proses interaksi antara pendidik dan peserta didik dapat berlangsung secara tepat guna dan berdaya guna (Netriwati, \& Lena, 2017). Selanjutnya, hamalik mengemukakan bahwa pemakaian media pembelajaran dalam proses pembelajaran dalam proses belajar mengajar dapat membangkitkan keinginan dan minat yang baru terhadap peserta didik, selain itu akan sangat 
membantu keefektifan proses pembelajaran dan penyampaian pesan dari isi pelajaran pada saat itu (Arsyad, 2016). Oleh karena itu, dalam pembelajaran media menjadi salah satu komponen penting yang dapat memberikan dukungan yang besar terhadap efektifitas pembelajaran.

Seiring dengan berkembangnya teknologi dan komunikasi sekarang ini, telah menghadirkan komputer sebagai media pembelajaran. Seperti yang dikatakan pendidik MTsN 2 Bandar Lampung Asnah Yusfit, S.Pd bahwa pemanfaatan komputer sebagai media pembelajaran masih belum maksimal. Komputer lebih banyak digunakan sebagai alat untuk dipelajari dalam pelajaran TIK bukan sebagai media pembelajaran, khususnya mata pelajaran selain TIK. Salah satu bentuk aplikasi komputer yang dapat digunakan dalam pembelajaran adalah multimedia. Multimedia merupakan bentuk teknologi komputer yang melibatkan berbagai media dalam satu perangkat lunak (software). Pemanfaatan multimedia ini dapat digunakan oleh pendidik untuk mempersentasikan materi pembelajaran dan memudahkan dalam proses belajar mengajar matematika dan membuat belajar mengajar menjadi lebih menarik dan tidak monoton.

Pembuatan multimedia ini menggunakan Macromedia Flash. Hal ini karena berbagai keunggulan yang dimilikinya yaitu disediakannya menu untuk menambahkan video dan audio serta animasi. Senada dikatakan oleh Meilani Safitri, menyatakan bahwa penggunaan multimedia berbasis flash dapat meningkatkan ketuntasan hasil belajar peserta didik hingga $85 \%$ dalam memahami materi yang diajarkan (Safitri, Hartono, \& Somakim, 2017). Selain itu, pembelajaran menggunakan multimedia dalam bentuk flash akan memiliki tingkat penguasaan materi secara signifikan lebih tinggi dibandingkan dengan materi yang hanya menggunakan materi dalam bentuk teks tertulis (Yusuf, 2015). Menurut Masykur dkk dalam penelitiannya mengungkapkan bahwa aplikasi macromedia flash mampu menciptakan animasi dan simulasi pembelajaran. Selain itu ditinjau dari hasil pembelajarannya bahwa respon peserta didik lebih tertarik pembelajaran menggunakan media pembelajaran berbasis macromedia flash.

Menurut Daitin Tarigan dalam (Jumiati \& Zulkifli, 2014.), pendekatan matematika realistik adalah pendekatan yang orientasinya menuju kepada penalaran peserta didik yang bersifat realistic dan ditujukan kepada pengembangan pola piker praktis, logis, kritis dan jujur dengan berorientasi pada penalaran matematika dalam menyelesaikan masalah.

Pendekatan Matematika Realistik merupakan pendekatan pembelajaran matematika yang berawal dari suatu masalah yang nyata kemudian dengan proses matematisasi berjenjang, dibawa menuju ke bentu formal dengan suasana pembelajaran yang menyenangkan. Dengan Pendekatan Matematika Realistik waktu akan lebih efisien dan peserta didik juga akan lebih mudah menerima pelajaran dikarenakan materinya dikaitkan dengan kehidupan sehari-hari.

Tujuan dari penelitian ini adalah (1) untuk mengetahui kelayakan dan kemenarikan multimedia pembelajaran dengan pendekatan PMR materi relasi dan fungsi. (2) untuk mengetahui tingkat keefektifan multimedia pembelajaran yang dikembangkan.

\section{METODE PENELITIAN}

Jenis penelitian yang digunakan dalam penelitian ini adalah penelitian 
pengembangan (Research and Development) yaitu metode penelitian untuk menghasilkan produk tertentu dan menguji keefektifan produk tersebut. Menurut Borg and Gall disederhanakan menjadi 7 langkah utama yaitu disesuaikan dengan penelitian yang akan dilakukan karena mengingat keterbatasan waktu dan biaya peneliti (Ekayana, Suharsono, \& Tegeh, 2013)

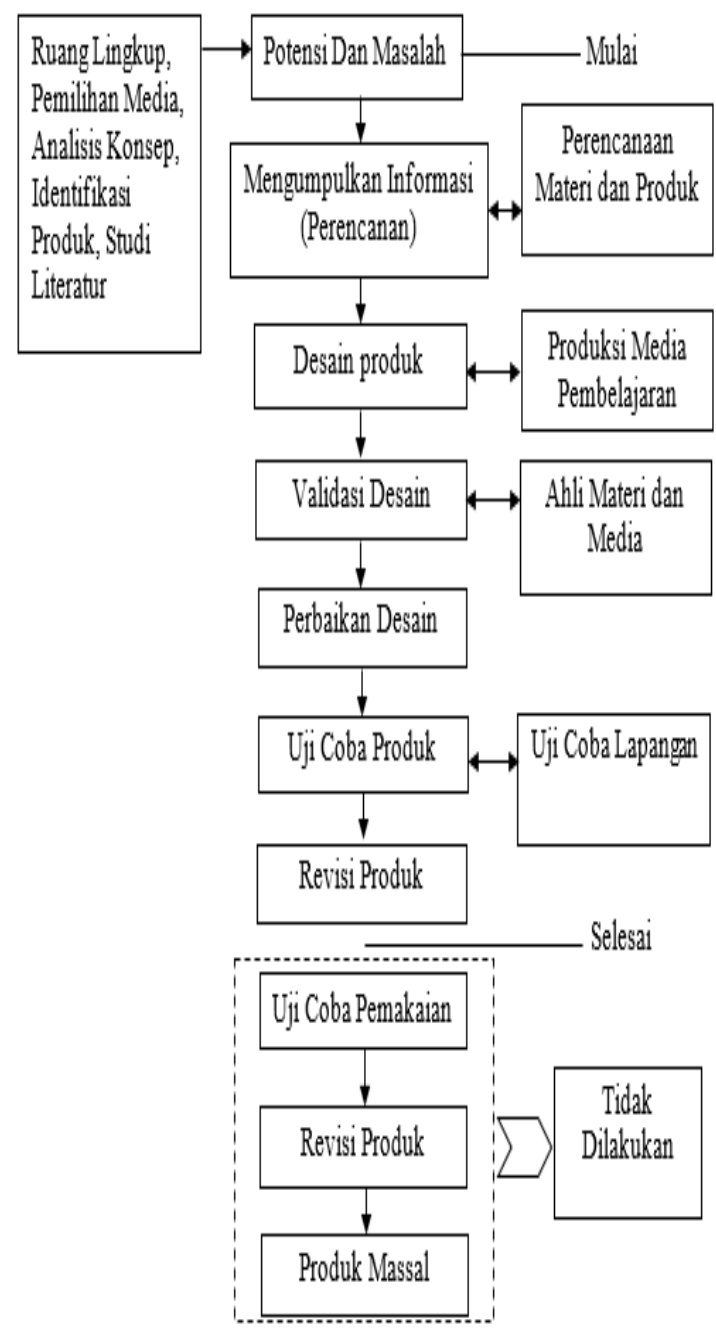

Gambar 1. Tahapan Pengembangan Penelitian

Subyek penelitian dan pengembangan ini adalah para ahli, yaitu ahli materi dan ahli media serta peserta didik kelas VIII MTs Neegeri 2
Bandar Lampung melalui uji coba kelompok besar yaitu 30 peserta didik.

Instrument yang digunakan dalam penelitian ini adalah : 1) Lembar validasi, digunakan untuk mengetahui apakah multimedia pembelajaran dan instrument yang telah dirancang valid atau tidak, lembar validasi berisi aspekaspek yang telah dirumuskan pada aspek penilaian isi atau materi, termasuk juga desain dan tata bahasa dalam media pembelajaran pada materi Relasi dan Fungsi. Masing-masing aspek dikembangkan menjadi beberapa pernyataan, lembar validasi ini diisi oleh ahli materi dan media, 2) Angket, disusun untuk meminta tanggapan peserta didik dalam penggunaan media pembelajaran yang dihasilkan, angket ini bertujuan pada media pembelajaran pada materi Relasi dan Fungsi.

Teknik pengumpulan data dalam penelitian ini adalah dengan menggunakan observasi, wawancara, dan angket. Observasi digunakan untuk memahami bagaimana kondisi objek yang akan diteliti. Wawancara dilakukan untuk mengetahui data awal dalam penelitian dan informasi yang diperoleh digunakan sebagai masukan untuk mengembangkan multimedia pembelajaran dengan pendekatan matematika realistik. Angket dalam penelitian ini menggunakan tiga tahap yaitu angket kebutuhan digunakan untuk mengambil data mengenai kebutuhan untuk mengembangkan media pembelajaran, angket validasi untuk mengumpulkan data tentang karakteristik dan kelayakan multimedia pembelajaran dan angket respon peserta didik tujuan nya untuk mengetahui respon peserta didik terhadap hasil pengembangan multimedia dengan pendekatan matematika realistik. Dokumentasi berupa foto agar dapat berguna untuk dijadikan bukti bahwasannya telah dilakukan penelitian. 
Teknik analisis data pada penelitian ini adalah menggunakan teknik analisis deskriptif kualitatif yang memaparkan hasil pengembangan produk yang berupa multimedia pembelajaran matematika dengan PMR materi Relasi dan Fungsi. Data yang diperoleh melalui instrumen uji coba dianalisis dengan menggunakan statistik deskriptif kualitatif. Analisis ini dimaksud untuk menggambarkan karakteristik data pada masing-masing variabel. Menghitung skor penilaian total dicari dengan rumus sebagai berikut: (Kesumayanti \& Putra, 2017).

Dengan :

$$
\bar{x}=\frac{\sum_{i=1}^{n} x_{i}}{n}
$$

$x_{i}=\frac{\text { jumlah } \text { skor }}{\text { skor maks }} \times 4$

Keterangan :

$\bar{x}=$ rata-rata akhir

$x_{i}=$ nilai uji operasional

$n=$ jumlah responden

Kemudian dianalisis dengan ketentuan skala likert yang terdiri dari 4 skala penilaian pada Tabel 1 .

Tabel 1. Skor Penilaian Validasi Ahli

\begin{tabular}{cc}
\hline Skor & $\begin{array}{c}\text { Pilihan Jawaban } \\
\text { Kelayakan }\end{array}$ \\
\hline 4 & Sangat Baik \\
3 & Baik \\
2 & Kurang Baik \\
1 & Sangat Kurang Baik \\
\hline
\end{tabular}

Kemudian hasil dari validasi dikelompokkan dalam kriteria interpretasi skor menurut skala likert disajikan pada Tabel 2. (Febriana, 2014)

Tabel 2. Kriteria Validasi

\begin{tabular}{lll}
\hline $\begin{array}{c}\text { Skor } \\
\text { Kualitas }\end{array}$ & $\begin{array}{c}\text { Kriteria } \\
\text { Kelayakan }\end{array}$ & Keterangan \\
\hline 3,26 & Valid/ Sangat & Tidak \\
$<$ & Layak & Revisi \\
$\bar{x} \leq 4,00$ & digunakan & \\
\hline
\end{tabular}

\begin{tabular}{lll}
\hline $2,51<$ & Cukup Valid & Revisi \\
$\bar{x} \leq 3,26$ & /Layak & Sebagian \\
& digunakan & \\
$1,76<$ & Kurang & Revisi \\
$\bar{x} \leq 2,51$ & Valid/Kurang & Sebagian \\
& Layak & \\
& digunakan & \\
$1,00<$ & Tidak & Revisi Total \\
$\bar{x} \leq 1,76$ & Valid/Tidak & \\
& Layak & \\
& digunakan & \\
\hline
\end{tabular}

Angket respon peserta didik terhadap penggunaan produk memiliki 4 pilihan jawaban sesuai konten pertanyaan. Masing-masing pertanyaan memiliki skor berbeda yang mengartikan tingkat kesesuaian produk bagi peserta didik disajikan pada Tabel 3. (Kesumayanti \& Putra, 2017)

Tabel 3. Skor Penilaian Pada Angket

\begin{tabular}{cc}
\hline Skor & $\begin{array}{c}\text { Pilihan Jawaban } \\
\text { Kelayakan }\end{array}$ \\
\hline 4 & Sangat Setuju \\
3 & Setuju \\
2 & Kurang Setuju \\
1 & Sangat Tidak Setuju \\
\hline
\end{tabular}

Kemudian hasil dari respon peserta didik tersebut dikelompokkan dalam kriteria interpretasi skor menurut skala likert sehingga diperoleh kesimpulan kelayakan media disajikan pada Tabel 4. (Herawati, 2016)

Tabel 4. Kriteria Interpretasi Kemenarikan

\begin{tabular}{cc}
\hline $\begin{array}{l}\text { Skor } \\
\text { Kualitas }\end{array}$ & Kriteria Kelayakan \\
\hline $3,26<$ & Sangat \\
$\bar{x} \leq 4,00$ & Menarik/Sangat \\
& Mudah digunaka \\
$2,51<$ & Menarik/Mudah \\
$\bar{x} \leq 3,26$ & digunakan \\
$1,76<$ & Kurang \\
$\bar{x} \leq 2,51$ & Menarik/Sulit \\
\hline
\end{tabular}


DOI: https://doi.org/10.24127/ajpm.v8i1.1711

\section{digunakan}

\begin{tabular}{cc}
$1,00<$ & Sangat Kurang \\
$\bar{x} \leq 1,76$ & Menarik/Sangat \\
& Sulit digunakan \\
\hline
\end{tabular}

Untuk mengetahui efektifitas produk pengembangan pada penelitian ini dilakukan dengan membandingkan pretest dan posttest pada saat uji coba lapangan. Peningkatan yang terjadi sebelum dan sesudah pembelajaran ini diperhitungkan dengan rumus $\mathrm{N}$-gain. Gain adalah selisih antara nilai pretest dan posttest. Gain menunjukkan peningkatan pemahaman atau penguasaan konsep peserta didik setelah pembelajaran yang dilakukan oleh pendidik. Klasifikasi $N$-gain disajikan pada Tabel 5. Adapun rumus $N$-gain (Rahmaniati \& Supramono, 2015)

$$
\begin{aligned}
& N-\text { gain }=\frac{S_{\text {post }}-S_{\text {pre }}}{S_{\text {maks }}-S_{\text {pre }}} \\
& \text { Keterangan : } \\
& S_{\text {post }}: \text { skor tes akhir } \\
& S_{\text {maks }} \text { : skor maksimum } \\
& S_{\text {pre }}: \text { : skor tes awal }
\end{aligned}
$$

Tabel 5. Klasifikasi Nilai Gain

\begin{tabular}{cc}
\hline Nilai & Klasifikasi \\
\hline (N-gain $) \geq 0,7$ & Tinggi \\
$0,7<(\mathrm{N}-$ & Sedang \\
gain $) \geq 0,3$ & \\
$(\mathrm{~N}-$ gain $) 0,3$ & Rendah \\
\hline
\end{tabular}

Sumber: (Hardiyantari, 2017)

\section{HASIL PENELITIAN DAN PEMBAHASAN}

Berikut ini hasil pengembangan multimedia pembelajaran materi relasi dan fungsi dengan pendekatan maematika realistik:

\section{Potensi dan Masalah}

Berdasarkan dari angket kuisioner peserta didik diperoleh bahwa sebagian peserta didik kurang menyukai pelajaran matematika dan banyak dari peserta didik menganggap bahwa media yang mereka gunakan masih biasa saja, peserta didik lebih tertarik dengan media yang menggunakan gambar animasi dan suara serta video. Sedangkan berdasarkan wawancara dengan guru matematika didapat bahwa media yang digunakan hanya buku paket 2013.

\section{Pengumpulan Data}

Dalam hal ini peneliti mengumpulkan informasi berupa sumber yang menunjang penyususunan multimedia pembelajaran, adapun refrensi yaitu: Buku matematika untuk SMP/MTs kelas VIII semester 1 karya Abdul Rahman As'ari, Muhammad Tohir, Erik Valentino serta buku matematika untuk SMP/MTs kelas VIII Semester 1 karya M.Cholik Adinawan.

\section{Desain Produk}

Penyusunan multimedia disesuaikan dengan kompetensi dasar yang termuat pada kurikulum 2013. Adapun perancangan penyajian isi dalam multimedia diantaranya materi relasi dan fungsi, contoh soal dan kuis. Tahap perancangan ini yang pertama yaitu pemilihan multimedia dan materi pembelajaran. Media yang dipilih yaitu Macromedia Flash dan Sparkol Videoscribe untuk lebih menarik minat peserta didik didalam pembelajaran terdapat gambar, audio serta animasi yang digunakan dalam kehidupan seharihari.pemilihan multimedia dan materi pembelajaran.

4. Validasi Desain

a. Hasil Validasi Ahli Materi 
Validasi ahli materi bertujuan untuk mengetahui mutu kelayakan isi, kelayakan bahasa, kelayakan penyajian dan kesesuaian matematika realistik dari produk yang dikembangkan. Validator multimedia pembelajaran melibatkan 3 orang validator, yaitu 2 dosen pendidikan matematika UIN Raden Intan Lampung dan 1 pendidik matematika MTs N 2 Bandar Lampung.

Hasil data validasi materi dapat dilihat pada Tabel 6 .

Tabel 6. Hasil Penilaian Validasi Ahli Materi

\begin{tabular}{|c|c|c|c|c|c|}
\hline \multirow{2}{*}{ Validator } & \multicolumn{4}{|c|}{ Skor Aspek } & \multirow{2}{*}{$\begin{array}{c}\text { Rata- } \\
\text { rata } \\
\text { Skor } \\
\end{array}$} \\
\hline & 1 & 2 & 3 & 4 & \\
\hline I & 3,1 & 3,3 & 3,7 & 3,3 & 3,3 \\
\hline II & 3,3 & 3,3 & 3,3 & 3,3 & 3,3 \\
\hline III & 3,5 & 3,7 & 3,3 & 4 & 3,6 \\
\hline \multicolumn{5}{|c|}{ Skor Akhir } & 3,4 \\
\hline
\end{tabular}

Berdasarkan Tabel 6 dapat disimpulkan validator ahli materi menyatakan bahwa materi yang terdapat di dalam media Valid dan siap untuk diuji cobakan.

\section{b. Hasil Validasi Ahli Media}

Validasi ahli media bertujuan untuk menguji efensiensi media, fungsi tombol dan kegrafikan pada multimedia pembelajaran dan berpendekatan matematika realistik. Validator multimedia pembelajaran melibatkan 3 orang validator, yaitu 2 dosen pendidikan matematika UIN Raden Intan Lampung dan 1 pendidik matematika MTs N 2 Bandar Lampung. Hasil validasi oleh ahli media disajikan pada Tabel 7.
Tabel 7. Hasil Penilaian Validasi Ahli Media

\begin{tabular}{ccccc}
\hline \multirow{2}{*}{ Validator } & \multicolumn{3}{c}{ Skor Aspek } & \multirow{2}{*}{$\begin{array}{c}\text { Rata-rata } \\
\text { Skor }\end{array}$} \\
\cline { 2 - 4 } & $\mathbf{1}$ & $\mathbf{2}$ & $\mathbf{3}$ & \\
\hline I & 3 & 3,5 & 3,5 & 3,3 \\
II & 3,3 & 3,5 & 3,3 & 3,4 \\
III & 3,5 & 3 & 3,5 & 3,3 \\
\hline \multicolumn{4}{c}{ Skor akhir } & \\
\end{tabular}

Berdasarkan Tabel 7 dapat disimpulkan validator ahli media menyatakan bahwa media Valid dan siap untuk diuji cobakan.

5. Revisi Desain

Setelah dilakukan validasi desain oleh para ahli materi dan ahli media selanjutnya revisi produk sesuai saran dan masukan yang telah diberikan oleh para ahli.

6. Uji Coba Produk

Uji coba dilakukan untuk mengetahui respon peserta didik terhadap kemenarikan produk yang telah dibuat serta mengetahui efektifitas dari produk tersebut.

a. Uji coba Lapangan

Uji coba lapangan dilakukan pada peserta didk kelas VIII MTsN 2 Bandar Lampung sebanyak 30 orang. Hasil angket respon peserta didik menunjukkan bahwa multimedia pembelajaran matematika dengan pendekatan matematika realistik "sangat menarik" dengan skor 3,33 .

b. Uji Efektifitas 
Setelah dilakukan uji lapangan, pada tahap berikutnya adalah uji efektifitas yaitu dengan mencari selisih skor posttest dan pretest untuk mengetahui hasil kegiatan pembelajaran yang terjadi sebelum dan sesudah menggunakan multimedia pembelajaran. Soal pretest diberikan sebelum peserta didik menggunakan multimedia pembelajaran sedangkan soal postets diberikan setelah peserta didik menggunakan multimedia pembelajaran. Berdasarkan tabel 8 , hasil postets dan pretest, dapat diketahui nilai tertinggi, nilai terendah, rata-rata dan selisih posttest dan pretest (gain score)

Tabel 8. Hasil Perhitungan Pretest dan Posttest

\begin{tabular}{llll}
\hline No & Kategori & Jumlah & $\begin{array}{c}\text { Persentase } \\
(\%)\end{array}$ \\
\hline 1 & Rendah & 0 & 0 \\
2 & Sedang & 13 & 41,94 \\
3 & Tinggi & 18 & 58,06 \\
\hline & Total & 31 & 100 \\
\hline
\end{tabular}

7. Revisi Produk

Setelah dilakukannya uji coba produk, produk dikatakan menarik sehingga tidak dilakukan uji coba ulang. Selanjutnya, media pembelajaran materi relasi dan fungsi ini bisa dimanfaatkan sebagai salah satu sumber belajar dan solusi untuk meningkatkan prestasi belajar dan memotivasi peserta didik untuk mengikuti proses belajar mengajar.

Multimedia pembelajaran yang dikembangkan yaitu berupa media Sparkoll VideoScribe dan Macromedia Flash dengan
Pendekatan Matematika Realistik pada materi Relasi dan Fungsi untuk peserta didik kelas VIII SMP/MTs. Media pembelajaran yang dikembangkan hanya dapat dijalankan melalui komputer. Media pembelajaran ini termasuk dalam kategori gabungan dari beberapa media. Hal ini sesuai dengan definisi Multimedia yaitu gabungan dari teks, gambar, seni, grafik, animasi, suara, dan video yang berada dalam suatu kontrol program komputer (Khuzaini \& Sudarmaji, 2017).

Multimedia pembelajaran dengan pendekatan matematika realistik pada materi relasi dan fungsi menggunakan Macromedia Flash berisi kompetensi, tujuan, materi, evaluasi dan profil. Pada kompetensi terdiri dari kompetensi inti dan kompetensi dasar. Tujuan berisikan tujuan pembelajaran. Materi dalam media pembelajaran dalam bentuk video. Evaluasi pada media berisikan kuis yang terdiri dari 20 soal pilihan ganda, 10 soal benar salah, dan 5 soal menjodohkan. Pada menu profil dapat dilihat foto peneliti dan biodata peneliti.

Beberapa penelitian yang telah dilakukan tentang multimedia pembelajaran menunjukkan hasil peserta didik mampu berpikir, mengeksplorasi, dan mengembangkan minat belajar, dan mengelaborasi inisiatif belajarnya, antusias dan kreatif dalam proses pembelajaran (Chen \& Chung, 2011). Penggunaan pendekatan matematika realistik yang dilakukan oleh Septika yang memberikan hasil bahwa pendekatan ini juga dapat meningkatkan hasil belajar matematika peserta didik ( Septika, 2013).

Selain materi dan tempat penelitian yang berbeda, penelitian 


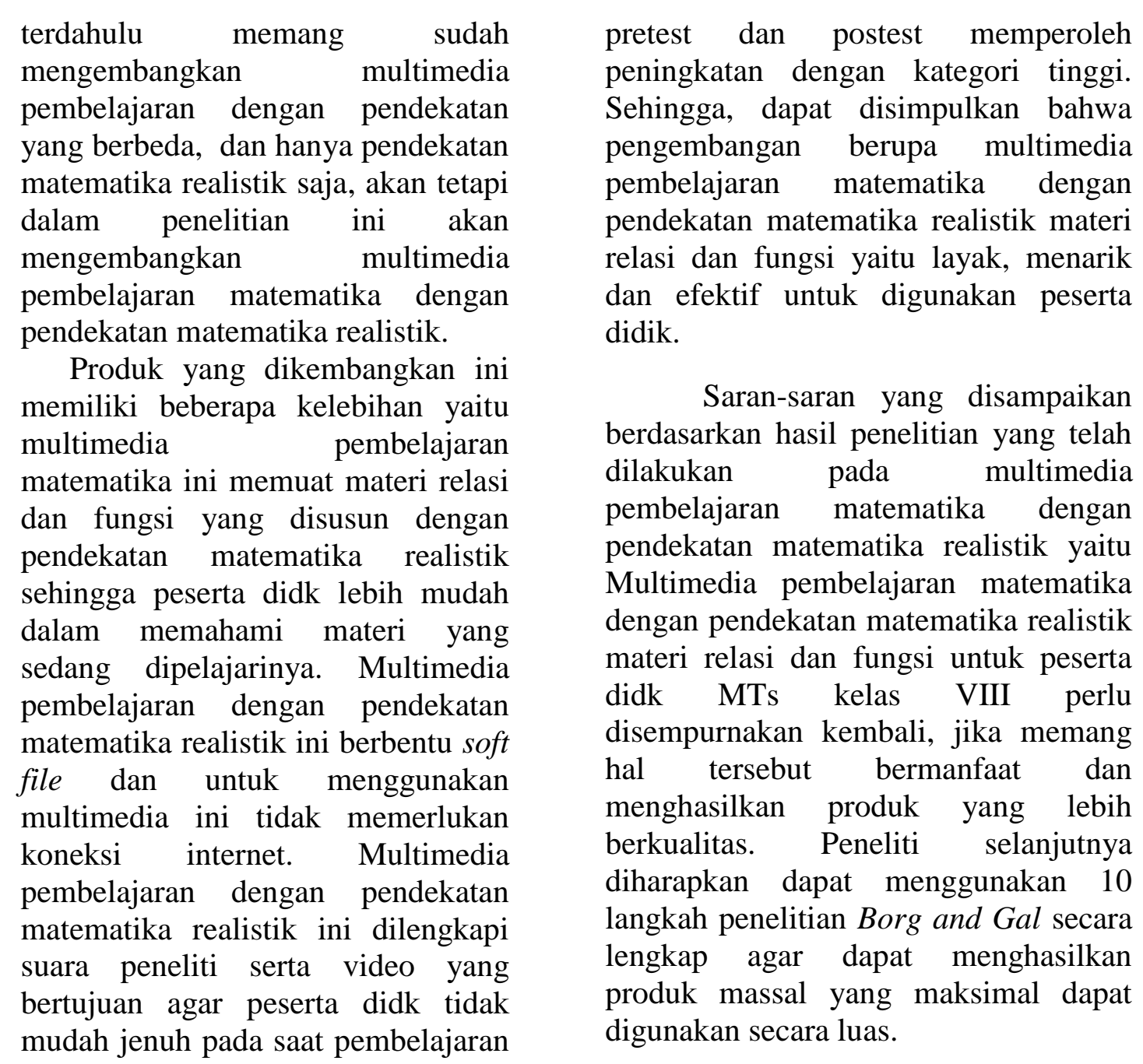
berlangsung.

Produk yang dikembangkan ini memiliki beberapa keterbatasan yaitu materi pada multimedia ini masih terbatas pada materi relasi dan fungsi saja. Multimedia hanya bisa dibuka diperangkat komputer saja.

\section{KESIMPULAN DAN SARAN}

Berdasarkan penelitian dan pembahasan yang telah dipaparkan, pengembangan multimedia pembelajaran telah divalidasi oleh ahli materi dan ahli media dengan memperoleh kriteria valid atau layak digunakan dan hasil uji coba kepada peserta didik memperoleh kategori sangat menarik selain itu, pada uji efektifitas menggunakan uji $\mathrm{N}$-gain

\section{DAFTAR PUSTAKA}
Arsyad, A. (2016). Media Pembelajaran. Jakarta: RajaGrafindo Persada.

Febriana, L. C. (2014). Pengembangan Lembar Kerja Siswa (LKS) Fisika Materi Tekanan Mencakup Ranah Kognitif, Afektif dan Psikomotor Sesuai Kurikulum 2013 Untuk Peserta didik SMP/MTs. Skripsi Jurusan Fisika FMIPA Universitas Negeri Malang.

Hardiyantari, O. (2017). Pengembangan multimedia pembelajaran 
DOI: https://doi.org/10.24127/ajpm.v8i1.1711

interaktif menggunakan teknik dinamis pada mata pelajaran produktif teknik komputer dan jaringan untuk siswa SMK kelas X. Jurnal Inovasi Teknologi Pendidikan, 4(1), 77-83.

Herawati, H. (2016). Pengembangan Modul Keanekaragaman Aves Sebagai Sumber Belajar Biologi. Jurnal Lentera Pendidikan Pusat Penelitian LPPM UM Metro, 1(1), 28-36.

Kesumayanti, N., \& Putra, R. W. Y. (2017). Pengembangan Bahan Ajar Materi Persamaan Kuadrat Berbantuan Rumus Cepat. JesMat (Jurnal Edukasi Dan Sains Matematika), 3(2), 125-138.

Mudlofir, A. dan Rusydiyah, E. F. (2016). Desain Pembelajaran Inovatif Dari Teori ke Praktik. Jakarta: RajaGrafindo Persada.

Netriwati \& Lena, M.S. (2017). Media Pembelajaran Matematika. Bandar Lampung: Permata Net.

Purwanti, R. D., Pratiwi, D. D., \& Rinaldi, A. (2016). Pengaruh Pembelajaran Berbatuan Geogebra terhadap Pemahaman Konsep Matematis ditinjau dari Gaya Kognitif. Al-Jabar: Jurnal
Pendidikan Matematika, 7(1), 115-122.

Putra, R. W. Y., \& Anggraini, R. (2016). Pengembangan Bahan Ajar Materi Trigonometri Berbantuan Software iMindMap pada Siswa SMA. Al-Jabar: Jurnal Pendidikan Matematika, 7(1), 39-47.

Rahmaniati, R., \& Supramono, S. (2015). Pembelajaran I-SETS (Islamic, Science, Environment, Technology and Society) terhadap Hasil Belajar Siswa. Anterior Jurnal, 14(2), 194-200.

Safitri, M., Hartono, Y., \& Somakim, S. (2017). Pengembangan media pembelajaran matematika pokok bahasan segitiga menggunakan macromedia flash untuk siswa kelas VII SMP. Jurnal Pendidikan, 14(2), 62-72.

Yusuf, A. M. (2015). Pengembangan Media Pembelajaran Berbasis Adobe Flash untuk Mata Kuliah Fisika Modern Materi Radiasi Benda Hitam. Jurnal Sains Dan Pendidikan Fisika, 11(1). 